\title{
Penerapan Model Quantum Teaching untuk Meningkatkan Hasil Belajar Siswa Kelas IV Sekolah Dasar
}

\author{
Rahmita Citra Dewi ${ }^{1)}$, Desyandri' ${ }^{2)}$, Yalvema Miaz ${ }^{3)}$ \\ ${ }^{1)}$ Mahasiswa, Universitas Negeri Padang, Indonesia \\ ${ }^{2}$ Pembimbing 1, Universitas Negeri Padang, Indonesia \\ ${ }^{3}$ Pembimbing 2, Universitas Negeri Padang, Indonesia
}

Email: ${ }^{1)}$ rahmitacitradewi@gmail.com, ${ }^{2)}$ desyandri@fip.unp.ac.id,,${ }^{3)}$ yalmiaz@gmail.com

\begin{abstract}
Abstrak
Penelitian ini bertujuan untuk mendeskripsikan penerapan model Quantum Teaching untuk meningkatkan hasil belajar siswa pada pembelajaran IPS. Penelitian ini adalah penelitian tindakan kelas yang menggunakan pendekatan kualitatif dan kuantitatif. Subjek penelitian ini adalah guru dan siswa kelas IV sebanyak 28 orang. Pelaksanaan penelitian ini dilakukan dalam dua siklus dengan prosedur penelitian yang terdiri dari perencanaan, pelaksanaan, pengamatan dan refleksi. Hasil penelitian menunjukkan peningkatan dalam segi a) RPP siklus I 83,9\% dan siklus II 92,8\%. b) Pelaksanaan aspek guru dan aspek siswa pada siklus I 80,5\% dan siklus II 94,4\%, c) Hasil belajar siswa pada siklus I 78,5 dan siklus II 87. Dengan demikian, penerapan model Quantum Teaching dapat meningkatkan hasil belajar siswa pada pembelajaran IPS di Kelas IV SD Negeri 08 Pisang Kota Padang.
\end{abstract}

Kata Kunci : Quantum Teaching; Hasil Belajar; IPS

\section{Application of Quantum Teaching Models to Improve the Fourth Grade Students Learning Outcomes in Elementary School}

\begin{abstract}
This study aims to describe the application of the Quantum Teaching model to improve student learning outcomes in social studies learning. This research is a classroom action research that uses qualitative and quantitative approaches. The subjects of this study were 28 teachers and fourth grade students. The implementation of this research was carried out in two cycles with research procedures consisting of planning, implementation, observation and reflection. The results of research was improve a) RPP cycle I $83.9 \%$ and cycle II 92.8\%. b) Implementation of teacher aspects and aspects of students cycle I $80.5 \%$ and cycle II 94.4\%, c) Student learning outcomes cycle I 78.5 and cycle II 87. Thus, the application of the Quantum Teaching model can improve learning outcomes students in social studies learning in Grade IV SD Negeri 08 Pisang Kota Padang.
\end{abstract}

Keyword: Quantum Teaching; Learning outcomes; Social science 


\section{PENDAHULUAN}

Mata pelajaran yang wajib diajarkan kepada siswa di SD salah satunya adalah mata pelajaran Ilmu Pengetahuan Sosial (IPS). IPS merupakan mata pelajaran yang di dalamnya memadukan berbagai cabang ilmu sosial yang mengkaji seperangkat peristiwa, fakta, konsep, dan generalisasi untuk pelatihan sikap, nilai, moral dan keterampilan berdasarkan konsep yang telah dimilikinya baik dalam lingkungan fisik maupun dalam lingkungan sosialnya.

Tujuan pembelajaran IPS yaitu mampu membekali siswa untuk mengembangkan konsep-konsep yang berkaitan dengan kehidupan masyarakat dan lingkungannya, mengembangkan kesadaran akan pentingnya rasa sosial di dalam diri dan rasa tanggung jawab didalam masyarakat. Selain itu di dalam pembelajaran IPS diharapkan siswa akan mampu mengatasi permasalahan yang dihadapi dalam konteks gobal, selain itu menjadi warga yang demokratis dan bertanggung jawab serta warga negara yang cinta damai (Miaz: 2012). Agar ter ciptanya keadilan sosial dalam kehidupan manusia diperlukan aktivitas pendidikan yang mengakomodir seluruh keberagaman tersebut (Desyandri, 2014). Di samping itu, "The importance of cultural values can give meaning that these values contain the values of wisdom that help human beings in organizing, conduct, and living life in family and society (Desyandri, 2017).

Guru harus mampu memperkenalkan konsep-konsep yang berhubungan dengan kehidupan masyarakat dengan menciptkan suasana belajar yang menyenangkan yaitu suasana yang dapat menarik minat siswa untuk berperan aktif dalam proses pembelajaran agar dapat membawa siswa pada pengalaman yang nyata serta mengkaitkannya dengan pengalaman yang telah siswa peroleh sebelumnya.

Berdasarkan hasil observasi yang peneliti lakukan di kelas IV SD Negeri 08 Pisang Kota Padang, peneliti menemukan beberapa permasalahan dari segi pelaksanaan pembelajaran IPS yaitu: media pembelajaran tidak sesuai dengan daya lihat siswa sehingga siswa kurang termotivasi untuk mengikuti pembelajaran, kurang diberikannya kesempatan kepada siswa untuk mengalami sendiri materi yang akan diajarkan sehingga nilai-nilai yang ada pada diri siswa kurang dapat ditingkatkan, kurangnya penanaman konsep materi yang berakibat siswa tidak dapat mengaitkan antara teori dan kenyataan yang dekat dengan siswa sehingga siswa hanya terfokus pada teori saja, kurangnya penghargaan kepada siswa atas pencapaian yang telah diperolehnya sehingga siswa kurang percaya diri dan kurang terpacu untuk berperan aktif dalam pembelajaran.

Berdasarkan permasalahan yang ditemukan pada pembelajaran IPS memberikan dampak terhadap hasil belajar siswa yang belum memuaskan yang ditandai dengan banyaknya siswa yang belum mencapai Kriteria Ketuntasan Minimum 
(KKM) yang telah ditentukan. Rendahnya hasil belajar ini sangat ditentukan oleh proses pembelajaran yang dilakukan guru, hal ini sejalan dengan pendapat berikut, bahwa, "The low learning outcomes of studentcan not be separated from the learning process that lasted for this" (Lenny Zaroha; Firman; Desyandri, 2018). Hal ini berarti bahwa hasil belajar siswa yang rendah tidak dapat dipisahkan dari proses pembelajaran. Sehingga guru perlu melakukan tindakan perbaikan pada proses pembelajaran, untuk mendapatkan hasil belajar yang maksimal. Sejalan dengan itu keberhasilan dalam proses pembelajaran ditentukan oleh beberapa faktor, bukan hanya guru dan siswa saja yang berperan aktif dalam pembelajaran tetapi juga didukung oleh aspek lain yaitu salah satunya model pembelajaran, seorang guru juga harus menentukan sebuah model yang cocok dalam sebuah pembelajaran karena kesalahan dalam pemilihan model maka dapat mengakibatkan tidak maksimalnya pencapaian hasil belajar (Banne,dkk, 2014:240).

Berdasarkan permasalahan yang telah dipaparkan diatas, peneliti memilih model Quatum Teaching karena dengan menggunakan model Quantum Teaching dapat memudahkan proses belajar dengan menguraikan cara-cara baru untuk memotivasi, dan mengarahkan keterlibatan siswa dalam kegiatan belajar secara visual, auditoral, dan kinestetik sehingga akan memacu semangat belajar siswa apapun jenis mata pelajarannya (DePorter, 2014:32). Model Quantum Teaching dipilih karena memiliki kelebihan dapat memberikan inspirasi kepada guru untuk menciptakan proses pembelajaran yang menyenangkan, yang menjadikan guru seperti cahaya yang dapat menuntun siswa mencapai kesuksesan karena siswa dirangsang untuk aktif mengamati, menyesuaikan antara teori dan kenyataan serta dapat mencoba melakukannya sendiri sehingga siswa dapat lebih kuat mengingat konsep-konsep yang dipelajari.

Berdasarkan latar belakang masalah yang telah diuraikan di atas, maka rumusan masalah secara umum adalah "Bagaimanakah Penerapan Model Quantum Teaching untuk Meningkatkan Hasil Belajar Siswa pada Pembelajaran IPS di Kelas IV SD Negeri 08 Pisang Kota Padang ?" sedangkan rumusan masalah secara khusus adalah mendeskripsikan bagaimanakah rencana pelaksanaan pembelajaran, pelaksanaan pembelajaran dengan menggunakan model Quantum Teaching, dan peningkatan hasil belajar siswa pada pembelajaran IPS ?

Sesuai dengan rumusan masalah di atas, maka tujuan dari penelitian ini secara umum ialah untuk mendeskripsikan penerapan model Quantum Teaching untuk meningkatan hasil belajar siswa pada pembelajaran IPS di Kelas IV SD Negeri 08 Pisang Kota Padang. Sedangkan secara khusus untuk mendeskripsikan bagaimana rencana pelaksanaan pembelajaran, 
pelaksanaan pembelajaran dengan menggunakan model Quantum Teaching, dan peningkatan hasil belajar siswa pada pembelajaran IPS.

\section{METODE PENELITIAN}

Jenis penelitian ini adalah Penelitian Tindakan Kelas (PTK) dengan menggunakan pendekatan kualitatif dan kuantitatif. Pendekatan kualitatif digunakan karena prosedur penelitian menghasilkan data deskriptif berupa kata-kata tertulis atau lisan serta perilaku yang diamati dari siswa. Pendekatan kuantitatif digunakan untuk menyajikan data numerik/angka-angka hasil belajar siswa.

Penelitian yang dilaksanakan ini terdiri dari dua siklus. Siklus I terdiri dari 2 kali pertemuan dan siklus II terdiri dari 1 kali pertemuan. Menurut pendapat Kemmis dan McTaggart (dalam Uno, 2012:87) bahwa "model siklus ini mempunyai empat komponen yaitu perencanaan, pelaksanaan, pengamatan, dan refleksi”.

Penelitian ini dilaksanakan di kelas IV SD Negeri 08 Pisang Kota Padang pada semester genap tahun ajaran 2017/2018. Subjek dalam penelitian ini adalah guru dan siswa kelas IV SD Negeri 08 Pisang Kota padang yang berjumlah 28 orang yang terdiri dari 11 orang laki-laki dan 17 orang siswa perempuan yang terdaftar pada semester II Tahun Ajaran 2017/2018.

Berdasarkan tahap pelaksanaan PTK di atas dapat diuraikan sebagai berikut: (1) persetujuan pihak sekolah, menetapkan jadwa penelitian, mengkaji KTSP mata pelajaran IPS kelas IV Semester II, menyusun RPP sesuai dengan tahapan model Quantum Teaching, membuat soal yang akan digunakan dalam pembelajaran baik objektif maupun essay, dan menyusun lembar observasi yang akan digunakan dalam pembelajaran. (2) Pelaksanaan, peneliti melaksanakan pembelajaran IPS dengan model Quantum Teaching sesuai dengan rancangan yang telah dibuat, observer melakukan pengamatan dengan format observasi, peneliti dan guru melakukan diskusi terhadap tindakan yaitu kegiatan memantau perencanaan dengan proses dan proses dengan hasil yang akan dilakukan, kemudian melakukan refleksi. pengamatan, melakukan pengamatan terhadap tindakan yang telah dilakukan dengan menggunakan instrumen yang telah dipersiapkan seperti lembar pengamatan RPP, aspek guru dan aspek siswa selama proses pembelajaran. (4) Refleksi, yaitu kegiatan menganalisis hasil pengamatan kelas, proses pembelajaran, rekap data hasil belajar, dan berbagi temuan lain sebagai dasar perencanaan untuk siklus berikutnya.

Teknik pengumpulan data penelitian dilakukan melalui observasi, tes dan non tes. Sementara itu instrumen penelitian yang digunakan antara lain: (1) Lembar observasi, (2) Lembar tes diukur dengan lembar penilaian kognitif berupa soal objektif dan essay, (3) Lembar non-tes digunakan untuk

Perencanaan, dimulai dengan meminta 
mendapatkan data tentang hasil belajar afektif dan psikomotor.

Analisis data dimulai dengan menelaah mulai dari pengumpulan data sampai seluruh data terkumpul. Data tersebut direduksi berdasarkan masalah permasalahan yang diteliti, diikuti dengan penyajian data dan yang terakhir penyimpulan data atau verifikasi. Tahap analisis ini dilakukan berulang-ulang sampai data selesai dikumpulkan. Analisis data kualitatif berhubungan dengan data hasil observasi pembelajaran, data observasi kegiatan guru dan data observasi kegiatan siswa. Sedangkan analisis data kuantitatif berhubungan dengan hasil belajar siswa.

\section{HASIL DAN PEMBAHASAN}

Pada bagian ini akan dipaparkan hasil penelitian dan pembahasan tentang penerapan model Quantum Teaching untuk meningkatkan hasil belajar siswa pada pembelajaran IPS di kelas IV SD Negeri 08 Pisang Kota Padang yang dilakukan mulai dari : 1) perencanaan, 2) pelaksanaan, 3) pengamatan, dan 4) refleksi.

Penelitian ini dilaksanakan dalam dua siklus, yakni siklus I dilaksanakan $2 \mathrm{x}$ pertemuan dan siklus II dilaksanakan $1 \mathrm{x}$ pertemuan.

Perencanaan pembelajaran IPS menggunakan model Quantum Teaching yang dilaksanakan menurut DePorter (2014:39-40) yaitu Tumbuhkan, Alami, Namai, Demonstrasikan, Ulangi, Rayakan dan disusun dalam bentuk RPP (Rencana
Pelaksanaan Pembelajaran), lembar penilaian RPP, lembar pengamatan pelaksanaan pembelajaran IPS dengan menggunakan Quantum Teaching (aspek guru dan aspek siswa), lembar penilaian hasil belajar siswa dengan penilaian kognitif berupa soal evaluasi, penilaian afektif berupa skala sikap, dan penilaian psikomotor berupa pengamatan saat demonstrasi. RPP ini disusun secara kolaboratif antara peneliti dengan guru kelas IV SD Negeri 08 Pisang Kota Padang. Sebelum RPP disusun, peneliti dan guru kelas terlebih dahulu menganalisis kompetensi dasar yang dikembangkan berdasarkan Kurikulum Tingkat Satuan Pendidikan (KTSP) dalam mata pelajaran Ilmu Pengetahuan Sosial kelas IV Semester II. Kompetensi Dasar (KD) yang diteliti adalah 2.3 Mengenal perkembangan teknologi produksi, komunikasi, dan transportasi serta pengalaman menggunakannya. Materi pembelajaran yang dibahas pada siklus I pertemuan 1 yaitu tentang perkembangan teknologi produksi dan pada pertemuan 2 membahas tentang perkembangan teknologi komunikasi.

Pelaksanaan pembelajaran pada siklus I melalui 3 kegiatan pembelajaran yang dimulai dari kegiatan awal, kegiatan inti, dan kegiatan akhir. Kegiatan awal dimulai dengan mengucapkan salam dan mengkondisikan kelas, kemudian berdoa dan guru mengecek kehadiran siswa, setelah itu siswa dan guru bersama-sama menyanyikan salah satu lagu wajib nasional "Garuda Pancasila" agar siswa dapat semangat dalam 
belajar dan selalu mencintai lagu-lagu nasional. Tindakan selanjutnya, guru memberikan sebuah teks "Perkembangan zaman dari waktu ke waktu" kepada siswa sebagai kegiatan literasi, setelah siswa selesai membaca teks kemudian dilanjutkan dengan appersepsi dan penyampaian tujuan pembelajaran.

Kegiatan inti, tahap 1 tumbuhkan, guru menampilkan gambar perkembangan teknologi produksi, dan komunikasi tradisional dan modern untuk memfokuskan, menumbuhkan, dan mengembangkan minat siswa untuk belajar. tahap 2 alami, guru mengajak siswa untuk mengamati gambar perkembangan teknologi yang telah dipajang kemudian melakukan tanya jawab seputar gambar yang dipajang kemudian guru memancing siswa untuk mengaitkannya dengan pengalaman yang pernah mereka alami. Tahap 3 Namai, guru memberikan kata kunci kepada siswa untuk membantu siswa dalam memahami materi tentang teknologi produksi dengan memperdalam materi menggunakan Lembar Kerja Siswa (LKS) dan memeriksanya. Tahap 4 demonstrasi, guru membagi siswa menjadi 5 kelompok yang terdiri dari 6 atau 5 orang setiap kelompoknya dan meminta perwakilan setiap kelompok untuk mendemonstrasikan sebuah perkembangan teknologi sesuai dengan langkah-langkah yang telah didemonstrasikan oleh guru dan dibuat dalam LDK. Tahap 5 ulangi, Guru memberikan kesempatan kepada siswa untuk menyimpulkan pelajaran yang telah dipelajari. Siswa menjelaskan pelajaran yang telah dipelajari yaitu perkembangan teknologi. Selanjutnya guru dan siswa menyimpulkan bersama-sama materi yang telah dipelajari. Tahap 6 rayakan, guru memberikan penghargaan kepada 5 orang siswa yang aktif selama mengikuti pembelajaran dan bersam-sama bertepuk tangan untuk merayakan pembelajaran hari itu.

Kegiatan akhir, peneliti memberikan penguatan, memberikan 10 pernyataan untuk penilaian afektif yang berkaitan dengan perkembangan teknologi. Kemudian siswa diminta merapikan tempat duduk dan bersyukur.

Selama kegiatan berlangsung,observer mengamati jalannya proses pembelajaran dengan mengamati RPP, aspek guru dan aspek siswa. Pengamatan penilaian RPP pada siklus I memperoleh rata-rata $83,9 \%$ sedangkan aspek guru dan siswa memperoleh rata-rata $80,5 \%$.

Penilaian yang dilakukan pada hasil belajar siswa dalam pembelajaran IPS terdiri dari ranah kognitif, afektif, dan psikomotor. Hasil belajar pada siklus I pada aspek kognitif memperoleh rata-rata 77,6 , aspek afektif memperoleh rata-rata 80,5 , dan psikomotor memperoleh rata-rata 77,5. Secara keseluruhan nilai yang diperoleh untuk hasil belajar siswa pada siklus I ialah 78,5 dengan kriteria baik.

Berdasarkan hasil pengamatan yang telah dilakukan masih terdapat beberapa kekurangan dari pengamatan RPP, 
pelaksanaan pembelajaran, dan hasil belajar pada siklus I yaitu pengorganisasian materi ajar kurang sesuai dengan alokasi waktu yang terdapat dalam RPP (melebihi waktu yang telah ditentukan dalam RPP). Hal ini disebabkan karena guru menyampaikan materi ajar kurang terorganisir dengan baik sehingga langkah-langkah pembelajaranpun kurang sesuai dengan alokasi waktu yang telah ditentukan. Sebagaimana yang dijelaskan Wotrubo dan Wright (dalam Uno, 2011:174) bahwa "pengorganisasian materi baik, dapat dilakukan dengan cara: guru mengaitkan materi yang akan disampaikan secara logis dan teratur, mengaitkan materi dengan tujuan pembelajaran dan menyesuaikannya dengan alokasi yang telah ditetapkan". Sedangkan pada pelaksanaan pembelajaran sudah baik namun masih ada beberapa tahapan yang belum di lakukan guru 1) Pada tahap alami, guru belum sepenuhnya membuka skemata siswa dan mengkaitkannya dengan pengalaman umum siswa, Seharusnya guru memberikan pengalaman umum tentang perkembangan teknologi yang menyangkut dalam kehidupan siswa dan memberikan perhatian penuh kepada setiap siswa agar siswa lebih mengerti dan bisa mengaitkan materi pembelajaran dengan kehidupan sehari-hari. Dimana DePorter (2014:10) mengatakan "ciptakan atau datangkan pengalaman umum yang dapat dimengerti semua siswa". 2) Pada tahap ulangi, guru tidak menanyakan apakah masih ada keraguan atau materi yang belum dipahami bagi siswa, hal ini disebabkan karena guru sudah mengira siswa sudah mengerti tentang materi yang diajarkan guru. Menurut DePorter (2014:10) "tunjukkan siswa cara-cara mengulang materi dan menegaskan bahwa aku tahu ini”. 3) Pada tahap rayakan, guru belum memberikan motivasi sepenuhnya kepada siswa yang belum memperoleh nilai yang baik, Menurut

DePorter (2014:10)"pengakuan untuk penyelesaian, partisipasi, dan pemerolehan keterampilan dan ilmu pengetahuan”. Pada kegiatan Akhir, guru belum memberikan penguatan tentang materi yang dipelajari dan belum memberikan tindak lanjut, untuk itu guru seharusnya bisa memberikan penguatan tentang materi yang sedang dipelajari dan bisa memberikan tindak lanjut dengan alternatif menugaskan dan memotivasi siswa membaca materi pembelajaran di rumah.

Berdasarkan hasil observasi, tes, serta non tes yang telah dilakukan maka dapat disimpulkan bahwa hasil belajar siswa belum mencapai kriteria keberhasilan yang diinginkan karena 16 orang sudah mencapai KKM namun 12 orang belum mencapai KKM dengan persentase $57,2 \%$.. Dengan demikian, penerapan model Quantum Teaching untuk meningkatkan hasil belajar IPS akan peneliti lanjutkan pada siklus II dengan lebih baik sesuai hasil refleksi yang telah dilakukan.

Penelitian siklus II ini dilaksanakan sebanyak 1 x pertemuan. Perencanaan pembelajaran IPS menggunakan model Quantum Teaching 
tidak jauh berbeda dengan perencanaan pembelajaran pada Siklus I yang disusun dalam bentuk RPP (Rencana Pelaksanaan Pembelajaran), lembar penilaian RPP, lembar pengamatan pelaksanaan pembelajaran IPS dengan menggunakan Quantum Teaching (aspek guru dan aspek siswa), lembar penilaian hasil belajar siswa dengan penilaian kognitif berupa soal evaluasi, penilaian afektif berupa skala sikap, dan penilaian psikomotor berupa pengamatan saat demonstrasi. RPP ini disusun secara kolaboratif antara peneliti dengan guru kelas IV SD Negeri 08 Pisang Kota Padang. Sebelum RPP disusun, peneliti dan guru kelas terlebih dahulu menganalisis kompetensi dasar yang dikembangkan berdasarkan Kurikulum Tingkat Satuan Pendidikan (KTSP) dalam mata pelajaran Ilmu Pengetahuan Sosial kelas IV Semester II. Materi pembelajaran yang dibahas tentang perkembangan teknologi transportasi.

Pelaksanaan pembelajaran pada siklus II melalui 3 kegiatan pembelajaran yang dimulai dari kegiatan awal, kegiatan inti, dan kegiatan akhir. Kegiatan awal dimulai dengan mengucapkan salam dan mengkondisikan kelas, kemudian berdoa dan guru mengecek kehadiran siswa, setelah itu siswa dan guru bersama-sama menyanyikan salah satu lagu wajib nasional "Ibu Kita Kartini" agar siswa dapat semangat dalam belajar dan selalu mencintai lagu-lagu nasional. Tindakan selanjutnya, guru memberikan sebuah teks "Perkembangan teknologi transportasi" kepada siswa sebagai kegiatan literasi, setelah siswa selesai membaca teks kemudian dilanjutkan dengan appersepsi dan penyampaian tujuan pembelajaran.

Kegiatan inti, tahap 1 tumbuhkan, guru menampilkan gambar perkembangan teknologi transportasi tradisional dan modern untuk memfokuskan, menumbuhkan, dan mengembangkan minat siswa untuk belajar. tahap 2 alami, guru mengajak siswa untuk mengamati gambar perkembangan teknologi transportasi yang telah dipajang kemudian melakukan tanya jawab seputar gambar yang dipajang kemudian guru memancing siswa untuk mengaitkannya dengan pengalaman yang pernah mereka alami. Tahap 3 Namai, guru memberikan kata kunci kepada siswa untuk membantu siswa dalam memahami materi tentang teknologi transportasi dengan memperdalam materi menggunakan Lembar Kerja Siswa (LKS) dan memeriksanya. Tahap 4 demonstrasi, guru membagi siswa menjadi 5 kelompok yang terdiri dari 6 atau 5 orang setiap kelompoknya dan meminta perwakilan setiap kelompok untuk mendemonstrasikan sebuah perkembangan teknologi transportasi sesuai dengan langkah-langkah yang telah didemonstrasikan oleh guru dan dibuat dalam LDK. Tahap 5 ulangi, Guru memberikan kesempatan kepada siswa untuk menyimpulkan pelajaran yang telah dipelajari. Siswa menjelaskan pelajaran yang telah dipelajari yaitu perkembangan 
teknologi. Selanjutnya guru dan siswa menyimpulkan bersama-sama materi yang telah dipelajari. Tahap 6 rayakan, guru memberikan penghargaan kepada 5 orang siswa yang aktif selama mengikuti pembelajaran dan bersama-sama bertepuk tangan untuk merayakan pembelajaran hari itu.

Kegiatan akhir, peneliti memberikan penguatan, memberikan 10 pernyataan untuk penilaian afektif yang berkaitan dengan perkembangan teknologi transportasi. Kemudian siswa diminta merapikan tempat duduk dan bersyukur.

Pengamatan dilakukan terhadap hasil penyusunan RPP, aspek guru dan aspek siswa. Pengamatan penilaian RPP pada siklus II memperoleh rata-rata $92,8 \%$ sedangkan aspek guru dan siswa memperoleh rata-rata $94,4 \%$.

Penilaian yang dilakukan pada hasil belajar siswa dalam pembelajaran IPS terdiri dari ranah kognitif, afektif, dan psikomotor. Hasil belajar pada siklus II pada aspek kognitif memperoleh nilai 88,2, aspek afektif memperoleh nilai 93,9, dan psikomotor memperoleh nilai 80,9. Secara keseluruhan nilai yang diperoleh untuk hasil belajar siswa pada siklus II ialah 87 dengan kriteria sangat baik.

Hasil penelitian yang dilakukan observer pada RPP sudah berjalan dengan sangat baik walapun masih ada salah satu deskriptor yang masih tertinggal pada kejelasan proses pembelajaran langkahlangkah pembelajaran belum sesuai dengan alokasi waktu yang telah ditentukan pada RPP . Hal ini disebabkan karena pengelolaan kelas yang dilakukan guru masih kurang sehingga mengakibatkan poses pembelajaran yang dilakukan melebihi waktu yang telah direncanakan dalam RPP. Untuk itu guru seharusnya dalam menyusun langkahlangkah pembelajaran haruslah disesuaikan dengan waktu.

Berdasarkan hasil observasi, tes, serta non tes yang telah dilakukan maka dapat disimpulkan bahwa hasil belajar siswa sudah mencapai KKM yang telah ditetapkan dengan 26 orang siswa sudah mencapai KKM hanya 2 orang yang belum mencapai KKM dengan persentase $92,8 \%$.

Pada perencanaan pelaksanaan pembelajaran di siklus II ini sudah menjadi acuan dalam melaksanakan kegiatan pembelajaran sehingga pembelajaran menjadi lebih terarah dan berjalan secara efektif. Maka dari itu peneliti tidak perlu melanjutkan ke siklus selanjutnya. Hal ini sesuai dengan pernyataan Kunandar (2011:263) "dengan menyusun rencana pembelajaran secara profesional, sistematis dan berdaya guna, maka guru akan mampu melihat, mengamati, menganalisis, dan memprediksi program pembelajaran sebagai kerangka kerja yang logis dan terencana".

\section{Hasil penerapan model Quantum} Teaching untuk meningkatkan hasil belajar siswa pada pembelajaran IPS dapat dilihat pada diagram dibawah ini: 

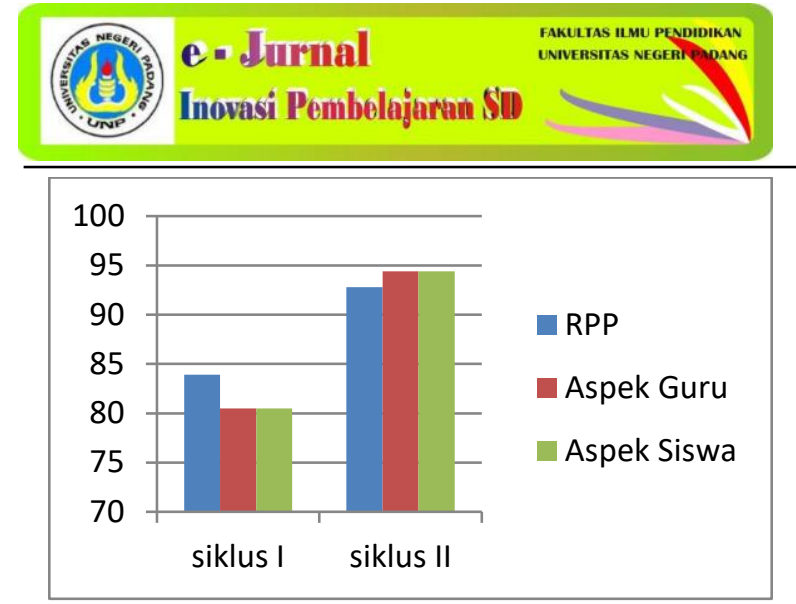

Diagram 1. Peningkatan perencanaan dan pelaksanaan pembelajaran IPS dengan menggunakan model Quantum Teaching siklus I dan siklus II.

Diagram 1 menggambarkan hasil pengamatan observer pada siklus I dan siklus II, diperoleh persentase pengamatan RPP pada siklus I yaitu 83,9\% (B) sedangkan hasil pengamatan siklus II 92,8\% (A). Dengan peningkatan sebesar $8,9 \%$. Pada pelaksanaan aspek guru dan siswa siklus I memperoleh persentase $80,5 \% \quad$ (B) sedangkan pada siklus II memperoleh persentase sebesar 94,4\% (A), dengan peningkatan sebesar $13,9 \%$.

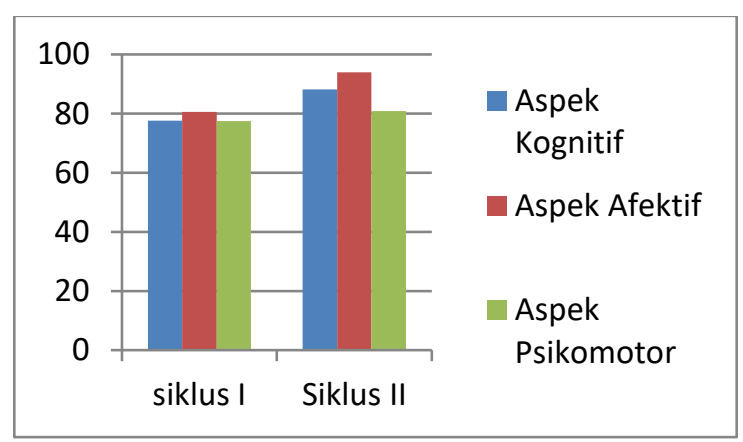

Diagram 2. Peningkatan hasil belajar siklus I dan siklus II.

Diagram 2 menggambarkan hasil belajar siswa pada siklus I dan siklus II dimana pada aspek kognitif siklus I memperoleh nilai 77,6 (B) sedangkan pada siklus II memperoleh nilai 88,2 (A). Aspek
Volume 6, Nomor 2, 2018

Available on: http://ejournal.unp.ac.id/students/index.php/pgsd

afektif siklus I memperoleh nilai 80,5 (B) sedangkan pada siklus II memperoleh nilai 93,9 (A). Dan pada aspek psikomotor siklus I memperoleh nilai 77,5 sedangkan pada siklus II memperoleh nilai 80,9.

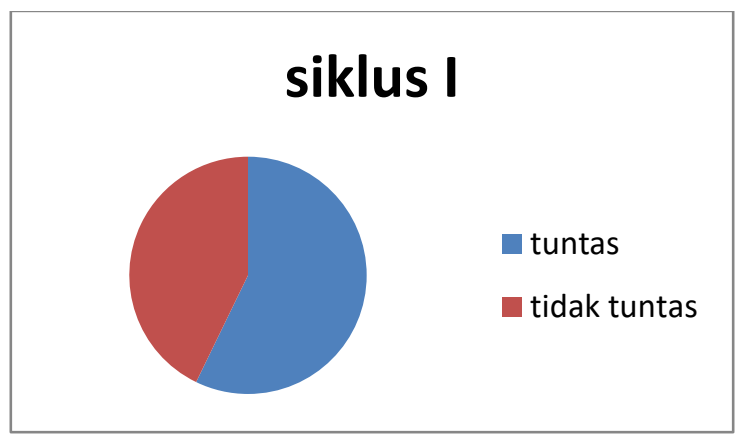

Diagram 3. Persentase ketuntasan Siklus I

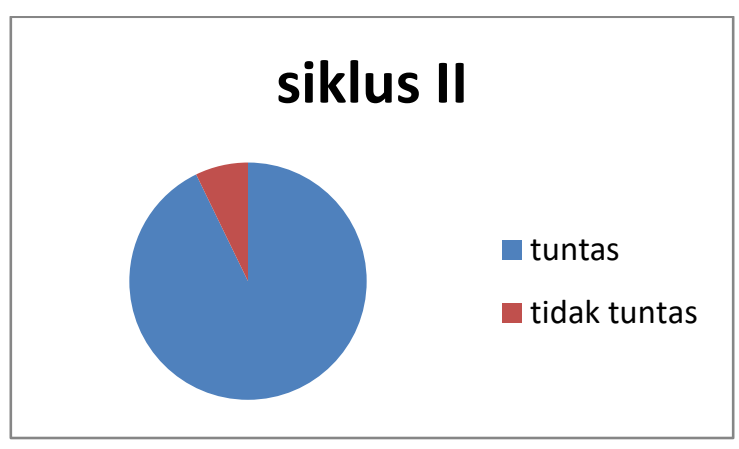

Diagram 4. Persentase ketuntasan siklus II

Diagram 3 dan 4 menunjukkan persentase ketuntasan siklus I dan siklus II. Pada siklus I dengan jumlah siswa 28 orang, terdapat 16 orang siswa yang sudah tuntas dengan persentase 57,2\%, sedangkan 12 orang siswa belum tuntas dengan persentase 42,8\%. Pada siklus II dengan jumlah siswa 28 orang terdapat 26 orang siswa yang sudah tuntas dengan persentase $92,8 \%$ sedangkan 2 orang siswa belum tuntas dengan persentase $7,2 \%$. Karena ketuntasan atau keberhasilan siswa sudah melebihi $75 \%$ maka penelitian dihentikan pada siklus II. 


\section{SIMPULAN}

1. Rencana pelaksanaan pembelajaran IPS di kelas IV SD Negeri 08 Pisang Kota Padang dengan menggunakan Model Quantum Teachingdituangkan dalam bentuk Rencana Pelaksanann Pembelajaran ( RPP). RPP dibuat sesuai dengan langkah-langkah Model Quantum Teaching. Perencanaan pembelajaran dibuat secara kolaboratif oleh peneliti dan guru kelas IV SD Negeri 08 Pisang Kota Padang. Perencanaan pembelajaran IPS dengan menggunakan model Quantum Teaching terdiri dari kegiatan awal, inti, dan akhir. Hasil Pengamatan RPP pada siklus I pertemuan 1 memperoleh nilai persentase $78,6 \%$ dan siklus I pertemuan 2 memperoleh nilai persentase $89,3 \%$. Nilai persentase rata-rata yang diperoleh pada siklus I adalah 83,9\% dengan kualifikasi baik (B) sedangkan hasil pengamatan pada siklus II adalah 92,8\% dengan kualifikasi sangat baik (A). Dapat disimpulkan bahwa hasil pengamatan RPP mengalami peningkatan dari siklus I ke siklus II sebesar $8,9 \%$.

2. Pelaksanaan pembelajaran IPS dengan penerapan Model Quantum Teaching ini dapat mengajarkan siswa untuk memahami materi pelajaran dan mengkaitkannya dengan pengalaman yang dimiliki siswa dalam kehidupan sehari-hari sehingga pembelajarannya menjadi lebih bermakna. Pembelajaran dilaksanakan sesuai dengan kerangka rancangan belajar model Quantum Teaching, yaitu : 1) Tumbuhkan, 2) Alami, 3) Namai, 4) Demosntrasikan, 5) Ulangi, dan 6) Rayakan. Hasil pengamatan pelaksanaan dari aktivitas guru dan siswa pada siklus I pertemuan 1 memperoleh nilai persentase $77,8 \%$ dan siklus I pertemuan 2 memperoleh nilai persentase $83,3 \%$. Nilai persentase rata-rata yang diperoleh pada siklus I adalah $80,5 \%$ dengan kualifikasi baik (B). Selanjutnya hasil pengamatan pada siklus II adalah 94,4\% dengan kualifikasi sangat baik (A). Dapat disimpulkan bahwa pelaksanaan mengalami peningkatan sebesar $13,9 \%$ baik dari aspek guru maupun aspek siswa.

3. Hasil belajar siswa dalam pembelajaran IPS dengan penerapan model Quantum Teachingternyata lebih meningkat dibandingkan dengan sebelumnya. Hal ini dapat dilihat dari hasil belajar siswa pada siklus II lebih tinggi dibandingkan dengan siklus I. Hasil belajar siswa pada siklus I memperoleh nilai rata-rata 78,5 dengan kualifikasi baik (B), sedangkan pada siklus II memperoleh nilai 87 dengan kualifikasi sangat baik (A). Dapat disimpulkan bahwa pelaksanaan mengalami peningkatan sebesar $8,5 \%$ baik dari aspek guru maupun aspek siswa. 


\section{DAFTAR RUJUKAN}

Banne, J., Dewi Bunga,dkk. (2014). Meningkatkan Hasil Belajar Siswa Pada Mata Pelajaran IPS Dengan Menggunakan Model Kooperatif Tipe STAD di Kelas IV SD Inpres 2 Langaleso. Langaleso: Universitas Tadulako.

http://download.portalgaruda.org/artic le.php?article $=296397 \& \mathrm{val}=5150$.

Vol 5 No 7. ISSN 2354-614X (diakses 15 Februari 2018)

DePorter, B, et. All. (2014). Quantum Teaching. Diterjemahkan oleh: Ary. Bandung: Kaifa Learning.

Desyandri. (2014). Peran Seni Musik dalam Pendidikan Multikultural. Jurnal Pembangunan Pendidikan; Fondasi Dan Aplikasi IP PPs UNY, 2(1), 1-11. https://doi.org/http://dx.doi.org/10.218 31/jppfa.v2i1.2613

Desyandri. (2017). Internalization of Local Wisdom Values through Music Art as Stimulation of Strengthening Character Education in Early Childhood Education; A Hermeneutic Analysis and Ethnography Studies. In ICECE 4th (Vol. 169, pp. 13-16). Padang: Atlantis Press. Retrieved from https://www.atlantispress.com/proceedings/icece$17 / 25889722$

Kunandar. (2011). Guru Profesional Implementasi Kurikulum Tingkat Satuan Pendidikan (KTSP) dan Sukses dalam Sertifikasi Guru. Jakarta: Rajawali

Miaz, Y. (2012). Peningkatan Hasil Belajar Siswa dalam Pembelajaran IPS dengan Menggunakan Metode Problem Solving di Sekolah Dasar. Padang: Universitas Negeri Padang. https://scholar.google.co.id/citations? user=uolxV54AAAAJ\&hl=id.

Vol.XII No.2 (diakses 4 aspril 2018)

Uno, H.B. (2011). Model Pembelajaran. Jakarta: Bumi Aksara.
Uno, H.B. (2012). Menjadi Peneliti PTK yang Profesional. Jakarta: Bumi Aksara.

Zaroha, L., Firman., Desyandri. (2018). The Effect of Using Quantum Teaching and Motivation in Learning Toward Students Achievement. JAIPTEKIN | Jurnal Aplikasi IPTEK Indonesia, 2(4),

https://doi.org/https://doi.org/10.2403 $6 / 4.32143$ 